\title{
PARADIGMA FILSAFAT ETIKA LINGKUNGAN DALAM MENENTUKAN ARAH POLITIK HUKUM LINGKUNGAN
}

\author{
${ }^{1}$ M.Yasir Said; ${ }^{2}$ Yati Nurhayati \\ ${ }^{1}$ Fakultas Hukum, Universitas Lambung Mangkurat \\ Jl.Brigjen Hasan Basry, Kota Banjarmasin 70123 \\ Email: yasirsaid93@gmail.com \\ Scopus ID: 57209336516 \\ ${ }^{2}$ Fakultas Hukum, Universitas Islam Kalimantan MAB \\ Jl.Adhyaksa No.2, Kota Banjarmasin 70123 \\ Email: yatinurhayati1904@yahoo.com \\ Scopus ID: 6507923727
}

\begin{abstract}
The idea of anthropocentric environmental is the main failure of values system that is still puts the interests of humans above other creatures. Human concern for sustainable life and nature which is reflected in the local culture that upholds the concept of environmental harmony, also begins to fade with the increasing demands of human life. This legal research and writing is focuses on: (1) Finding the philosophical framework for environmental ethics to preserve the environments; (2) Examine how the paradigm of environmental ethics can be used as the direction of Indonesian environmental-legal politics. This research uses the doctrinal (normative) method in addition of conceptual and historical approach. The results of this study show that the environment according to the ecosentrime is in line with the theory of corrective justice by Aristotle, it can be interpreted as to gave 'rights' for the environment. Whereas to determine the direction of the constituendum. It is necessary to focus on improving the legal culture rather than merely increasing the law itself.
\end{abstract}

Keywords: Environmental Ethics; Legal Politics; Environmental law; Ecosentrim.

\begin{abstract}
Abstrak
Tata nilai yang menyebabkan meningkatnya pencemaran dan perusakan lingkungan adalah masih dianutnya etika lingkungan yang anthropocentric. Etika ini menempatkan kepentingan manusia di atas kepentingan makhluk lainnya. Kepedulian manusia untuk menjunjung keberlanjutan hidup dan alam yang tercermin dalam nilai-nilai kearifan lokal yang menjunjung konsep pemeliharaan lingkungan, juga mulai pudar seiring dengan meningkatnya tuntutan hidup manusia dalam memenuhi kebutuhannya. Adapun penelitian dan penulisan hukum ini memusatkan pada permasalahan yakni: (1) Menemukan kerangka pemikiran filsafat etika lingkungan (environmental ethics) dalam upaya menjaga kelestarian lingkungan hidup; (2) Mengkaji bagaimana paradigma perkembangan etika lingkungan dapat digunakan sebagi arah politik hukum lingkungan Indonesia. Penelitian ini menggunakan
\end{abstract}


metode penelitian doctrinal (normative) dengan pendekatan konseptual dan pendekatan historis. Hasil dari penelitian ini menunjukan bahwa lingkungan hidup menurut aliran ekosentrime apabila dikaitkan dengan teori keadilan korektif oleh Aristoteles, dapat dimaknai sebagai adanya suatu 'hak' yang diberikan kepada lingkungan hidup. Sedangkan untuk menentukan arah ius constituendum hukum lingkungan Indonesia diperlukan fokus perbaikan budaya hukum daripada semata-mata peningkatan substansi.

Kata Kunci: Etika Lingkungan; Politik Hukum; Hukum Lingkungan; Ekosentrime.

\section{PENDAHULUAN}

Permasalahan lingkungan secara global semakin meningkat seiring dengan perkembangan industri dan jumlah penduduk terutama di negara-negara berkembang, Bahwa kualitas lingkungan yang semakin rusak tidak dapat diperbaiki dan dipulihkan kembali seperti sediakala (irreversible environmental damage). ${ }^{1} \mathrm{Jika}$ ditarik benang merahnya, maka terganggunya kualitas lingkungan hidup tidak terlepas dari pemanfaatan sumber daya alam yang serampangan dan berlebihan (over exploitation of natural resources). Terjadinya pencemaran tidak secara seketika tetapi melalui proses penurunan kualitas lingkungan secara bertahap. Diawali dengan pengotoran oleh

\footnotetext{
${ }^{1}$ Merujuk pada pendapat $R$. Stewart dan $J$. E. Krier bahwa masalah lingkungan umumnya tiga hal, yakni: (1) Pencemaran lingkungan (pollution); (2) Penggunaan atau pemanfaatan lahan yang salah (land misuse); dan (3) Pengerukan secara berlebihan yang menyebabkan habisnya sumber daya alam (natural resource depletion). Lihat Stewart, Richard and James E Krier. (1978). Environmental Law and Policy, New York: The Bobbs Merril Co. Indianapolis, hlm. 3-5.
}

materi atau zat tertentu dalam jangka waktu lama. ${ }^{2}$

Sehingga dari penjelasan tersebut, pencemaran mengakibatkan tidak berfungsinya lingkungan dalam mendukung kehidupan manusia. Dapat dikatakan pula, pencemaran yang terjadi secara terus-menerus akan mengakibatkan timbulnya kerusakan lingkungan. Di samping menimbulkan kerusakan alam, pencemaran juga akan mengakibatkan berbagai kerusakan bagi alam dan makhluk hidup yang ada di dalamnya. Lebih lanjut Daniel Callahan dalam The Tyranny of Survival menjelaskan bahwa teknologi merupakan salah satu komponen yang berdampak pada penurunan kualitas

2 "Pencemaran adalah suatu keadaan, dalam mana suatu zat atau energy diintroduksikan ke dalam suatu lingkungan oleh kegiatan manusia atau oleh proses alam sendiri dalam konsentrasi sedemikian rupa, hingga menyebabkan terjadinya perubahan dalam keadaan termaksud mengakibatkan lingkungan itu tidak berfungsi seperti semula dalam arti kesehatan, kesejahteraan dan keselamatan hayati". Lihat Danusaputro, Munadjat. (1986). Hukum Lingkungan dalam Pencemaran Lingkungan Melandasi Sistem Hukum Pencemaran, Bandung: Bina Cipta, hlm. 77. 
lingkungan hidup. ${ }^{3}$ Hal ini dapat dilihat pada kasus kebocoran pabrik pestisida milik Union Carbide di Kota Bhopal, India dan meledaknya reaktor nuklir di Chernobyl, Uni Soviet.

Adapun faktor ekonomi juga sangat berpengaruh. Keinginan untuk mengeruk keuntungan dengan memanfaatkan sebesar-besarnya sumber daya alam, memacu negara-negara di dunia untuk mengeksploitasi sumber daya alam yang dimiliki, yang secara kumulatif mengakibatkan penurunan kualitas dan kuantitas sumber daya tersebut. Selain itu ada pula faktor politik. Pada faktor ini masih erat kaitannya dengan kepentingankepentingan yang ada antara negara-negara maju dan negara berkembang dan negara miskin. Menjadi masalah apabila sistem politik dari negara-negara tersebut tidak mendukung terhadap rehabilitasi lingkungan, di mana masalah utama dari negara berkembang dan negara miskin adalah keterbatasan anggaran/ kurangnya dana rehabilitasi lingkungan.

Faktor terakhir adalah tata nilai. Kehidupan manusia selalu bertalian dengan tata nilai yang dianggap baik serta dipahami sebagai cara berpikir yang diwujudkan dalam etika dan tindakan

${ }^{3}$ Daniel Callahan dalam Ginting. (2012). Teori Etika Lingkungan, Bali: Udayana University Press, hlm. 13. manusia. Ada sejumlah kebiasaan dan nilai di Indonesia dan negara lain yang memiliki tata nilai yang sangat bersahabat dengan lingkungan. Ajaran agama juga selalu mengajarkan nilai untuk menghormati dan tidak merusak alam dan lingkungan.

Jika dilihat dari penjelasan di atas, maka dapat dikatakan tata nilai yang menyebabkan meningkatnya pencemaran dan perusakan lingkungan adalah masih dianutnya etika lingkungan yang anthropocentric. Etika ini menempatkan kepentingan manusia di atas kepentingan makhluk lainnya. Oleh karena itu, segala sesuatu yang ada di alam dimanfaatkan sebesar-besarnya untuk memenuhi kebutuhan dan kepentingan manusia semata. Dalam pendekatan antroposentrisme, seringkali dianggap posisi manusia berada di luar dan terpisah dari lingkungannya. Oleh karena menganggap bahwa keberadaan lingkungan tersebut diperuntukkan sematamata untuk kepentingan manusia, kita sering kali lupa memeliharanya. ${ }^{4}$

Selain nilai anthropocentric, kepedulian manusia untuk menjunjung

\footnotetext{
4 Erri Megantara, "Pendekatan Pembangunan Antroposentris Vs Ekosentris", Koran Republika, 11 Januari 1997, dalam Supariadi. (2008). Hukum Lingkungan Indonesia Sebuah Pengantar, Jakarta: Sinar Grafika, hlm. 40. Untuk memahami sejarah pergeseran nilai ini, baca lebih lanjut dalam Roderick Nash, Frazier. (1989). The Rights of Nature: A History of Environmental Ethics, terbitan University of Wisconsin Press.
} 
keberlanjutan hidup dan alam yang tercermin dalam nilai-nilai kearifan lokal yang menjunjung konsep pemeliharaan lingkungan, juga mulai pudar seiring dengan meningkatnya tuntutan hidup manusia dalam memenuhi kebutuhannya. Bertolak dari realitas yang ada, bumi dan seluruh sumber daya alam yang ada di dalamnya tidak dapat dijadikan sebagai objek untuk pemenuhan kebutuhan dan kesenangan manusia belaka, tapi harus ditempatkan sebagai subjek yang setara dengan manusia.

\section{RUMUSAN MASALAH}

Adapun berdasarkan latar belakang sebagaimana dijelaskan sebelumnya maka penelitian dan penulisan hukum ini memusatkan pada permasalahan yakni:

1. Bagaimana kerangka pemikiran filsafat etika lingkungan (environmental ethics) dalam upaya menjaga kelestarian lingkungan hidup?

2. Bagaimana kajian dari paradigma perkembangan etika lingkungan dapat digunakan sebagai arah politik hukum lingkungan Indonesia?

\section{TUJUAN PENELITIAN}

Adapun berdasarkan latar belakang sebagaimana dijelaskan sebelumnya maka penelitian dan penulisan hukum ini memusatkan pada permasalahan yakni:

1. Menemukan kerangka pemikiran filsafat etika lingkungan (environmental ethics) dalam upaya menjaga kelestarian lingkungan hidup.

2. Mengkaji bagaimana paradigma perkembangan etika lingkungan dapat digunakan sebagi arah politik hukum lingkungan Indonesia.

\section{METODE PENELITIAN}

Secara hakekat, ilmu hukum berusaha untuk menampilkan hukum secara integral sesuai dengan kebutuhan kajian ilmu hukum itu sendiri. ${ }^{5}$ Penelitian hukum yang digunakan dalam penelitian ini adalah penelitian hukum normatif (normative legal research). Metode ini dipilih karena obyek kajian penelitian adalah mengenai asas dan prinsip hukum, kaidah hukum, teori dan doktrin hukum dari para ahli hukum. ${ }^{6}$ Peter Mahmud

5 Yati Nurhayati, "Perdebatan Antara Metode Normatif Dengan Metode Empirik Dalam Penelitian Ilmu Hukum Ditinjau Dari Karakter, Fungsi, dan Tujuan Ilmu Hukum" Jurnal Al Adl, Vol 5, No 10 (2013), hlm.15

6 Penelitian hukum normatif adalah penelitian hukum yang meletakan hukum sebagai sebuah bangunan sistem norma. Sistem norma yang dimaksud adalah mengenai asas-asas, norma, kaidah dari peraturan perundangan, putusan 
Marzuki menjelaskan penelitian hukum normatif (Penelitian Hukum) dilakukan untuk menghasilkan argumentasi, teori atau konsep baru sebagai preskripsi dalam menyelesaikan masalah yang dihadapi. ${ }^{7}$ Adapun dalam hal ini peneliti menggunakan pendekatan konsep (conceptual approach) dan pendekatan historis (historical approach). Soerjono Soekanto dan Sri Mamudji memperkuat pendapat mengenai penelitian normatif adalah penelitian yang dilakukan dengan cara meneliti: ${ }^{8}$

a. Penelitian terhadap asas-asas hokum, yaitu penelitiian terhadap unsur-unsur hukum baik unsur ideal (normwissenschaft sollenwissenschaft) menghasilkan kaidah-kaidah hukum melalui filsafat hukum dan unsur real (tatsachenwissenschaft / seinwissenschaft) menghasilkan tata hukum tertentu (tertulis).

b. Penelitian terhadap sistematika hukum, yaitu mengadakan identifikasi terhadap pengertian pokok dalam hukum seperti subyek

pengadilan, perjanjian serta doktrin (ajaran). Mukti Fajar dan Yulianto Ahmad. (2009). Dualisme Penelitian Hukum: Normatif dan Empirirs, Yogyakarta: Pustaka Pelajar, hlm. 33- 38

7 “... suatu proses untuk menemukan suatu aturan hukum, prinsip prinsip hukum, maupun doktrin-doktrin hukum untuk menjawab permasalahan hukum yang dihadapi. ... Penelitian hukum normatif dilakukan untuk menghasilkan argumentasi, teori atau konsep baru sebagai preskripsi dalam menyelesaikan masalah yang dihadapi. Peter Mahmud Marzuki. (2005). Penelitian Hukum, Jakarta: Kencana., hlm. 35

8 Soerjono Soekanto dan Sri Mamuji. (1995). Penelitian Hukum Normatif, Suatu Tinjauan Singkat, Jakarta: RajaGrafindo, hlm. 15. hukum, hak dan kewajiban, peristiwa hukum dalam peraturan perundangan.

c. Penelitian terhadap taraf sinkronisasi vertikal dan horizontal, yaitu meneliti keserasian hukum positif (peraturan perundagan) agar tidak bertentangan berdasarkan hierarki perundang-undangan (stufenbau theory).

d. Perbandingan hukum, yaitu membangun pengetahuan umum mengenai hukum positif dengan membandingkan sistem hukum di satu negara dengan sistem hukum di negara lainnya

e. Sejarah hukum, yaitu meneliti perkembangan hukum positif (peraturan perundangan) dalam kurun waktu tertentu (misalnya hukum tanah, perkawinan, perpajakan perusahaan dsb).

Sementara itu Sutadnyo Wigyosubroto memberikan istilah penelitian doktrinal, yaitu penelitian terhadap hukum yang dikonsepkan dan dikembangkan atas dasar doktrin yang dianut sang pengkonsep atau sang pengembangnya. Penelitian hukum doktrinal tersebut dibagi menjadi 3 bagian, yaitu ${ }^{9}$ :

a. Penelitian doktrinal yang mengkaji hukum yang dikonsepkan sebagai asas hukum alam dalam sistem moral menurut doktrin hukum alam;

b. Penelitian doktrinal yang mengkaji hukum yang dikonsepkan sebagai kaidah perundang-undangan menurut doktrin positivism;

\footnotetext{
${ }^{9}$ Ibid.
} 
c. Penelitian doktrinal yang mengkaji hukum yang dikonsepkan sebagai keputusan hakim in concreto menurut doktrin realisme.

\section{PEMBAHASAN}

\section{Etika Lingkungan (Environmental} Ethics) Sebagai Hasil PemikiranPemikiran Filsafat Moral dan Filsafat Lingkungan

Filsafat, seperti kehidupan, adalah suatu proses pemeriksaan kembali yang terus-menerus, karena filsafat adalah suatu penyulingan khas bagian sadar dari kehidupan kita. Filsafat adalah suatu bagian penting dari citra diri kita, yang kita bentuk dalam interaksi dengan dunia luar, dengan sejarah masa lampau kita dan mimpi-mimpi masa depan kita, sebagaimana diutarakan Skolimowski bahwa tanpa filsafat maka tidak mempunyai arah, tidak mempunyai pengertian akan makna hidup. ${ }^{10}$ Konsep filsafat memang terdengar mengawang dan abstrak, tapi proses abstraksi itu diperlukan untuk menerangi pengalaman dan melihat

10 Skolimowski adalah professor filsafat pada Departement of Humanities, University of Michigan, Ann Arbor yang berpendapat "Without philosophy, we have no anchor, no direction, no sense of the meaning of life. Each epoch and each society is rooted in some fundamental beliefs and assumptions, which are acted upon as if they were true. They justify all other things that follow from them, while they themselves are accepted on faith." Lihat Skolimowski, Henryk. (1981). Ecophilosophy: Designing New Tactics for Living. New Hampshire: Marion Boyars Inc.,hlm. 21. akar-akar dasar tersembunyi di balik segala persoalan konkret. ${ }^{11}$ Tujuan filsafat yang sebenarnya menurut Kattsoff adalah untuk menyusun suatu pandangan dunia. Pentingnya pandangan dunia mudah dimengerti bila kita memandang zaman kita sendiri. Zaman ini ditandai oleh pandangan dunia yang tampak tidak lengkap dan berada dalam proses perubahan. $^{12}$

Suatu perubahan di dalam filsafat menurut Skolimowski adalah suatu perubahan dalam prinsip-prinsip utama keyakinan yang diterima, entah keyakinan itu berwatak religius atau sekuler. Dan sebaliknya, ketika suatu warga, masyarakat, atau peradaban tertentu diguncang atau dihancurkan, dibutuhkan pemikiran segar, yang faktanya, lebih sering merupakan suatu landasan filosofis yang baru. ${ }^{13}$ Sugiharto mengemukakan bahwa 'modernisme' di bidang filsafat adalah gerakan pemikiran dan gambaran dunia tertentu yang awalnya diinspirasikan oleh Descartes, dikokohkan oleh gerakan Pencerahan (Enlightement/Aufklarung). ${ }^{14}$

11 Bambang Sugiharto, "Filsafat dan Pengalaman", Pengantar buku Gaarder, Jostein. (1996), Dunia Sophie: Sebuah Novel Filsafat, Bandung: Mizan, hlm. 14-15.

12 Kattsoff, Louis O. (2004), Pengantar Filsafat, Yogyakarta: Penerbit Tiara Wacana Yogya, hlm. 455.

${ }^{13}$ Skolimowski, Op. Cit., 31-32.

14 Sugiharto, Bambang. (1996). Postmodernisme: Tantangan Bagi Filsafat. Yogyakarta: Kanisius, hlm. 29. 
Pada taraf praksis, pandangan dualistiknya yang membagi seluruh kenyataan menjadi subjek dan objek, spiritual-material, manusia-dunia, dan sebagainya, telah mengakibatkan objektivisasi alam secara berlebihan dan pengurasan alam semenamena, yang telah mengakibatkan krisis ekologi. Modernisme ${ }^{15}$ bidang filsafat sebagaimana dikemukakan oleh Sugiharto di atas merupakan filsafat kontemporer ${ }^{16}$ seperti yang diutarakan oleh Skolimowski. Filsafat kontemporer merupakan filsafat empirisis, analitis, yakni aliran ilmiah Barat dewasa ini. Filsafat tidak hanya mendominasi kajian universitas-universitas Anglo-Saxon, tetapi secara tidak langsung telah menjadi filsafat yang diterima secara global. $^{17}$

Skolimowski kemudian mencoba menawarkan filsafat lingkungan sebagai

\footnotetext{
15 Ibid.

16 Filsafat kontemporer adalah cara pandang dan berpikir mendalam menyangkut kehidupan pada masa saat ini. Filsafat kontemporer memiliki sifat yang sangat heterogen. Filsafat kontemporer mensyaratkan kebebasan dan tidak selalu harus simetris. Aliran-aliran filsafat kontemporer antara lain: eksistensialisme, pragmatisme, postmodernisme, strukturalisme, fenomenologi, neo-thomisme, vitalisme, filsafat analitis.

${ }^{17}$ Skolimowski menyatakan: "Kita berada pada periode kegemparan dan kekacauan yang lain, di mana kita harus menantang batas-batas pemahaman analitis dan empiris atas dunia seraya kita harus menyusun suatu kerangka kerja konseptual dan filosofis yang dapat menampung seabrek masalah sosial, etis, ekologis, epistemologis yang baru. Perlunya suatu kerangka kerja filosofis yang baru dirasakan oleh hampir setiap orang." Skolimowski, op. cit., 33-34, dan 39.
}

suatu tantangan yang memiliki persoalanpersoalan yang cukup signifikan untuk membuat para filsuf (dan bukan hanya para filsuf) merefleksikan, merenungkan, mengkaji ulang, mengusulkan wawasan, dan kebenarankebenaran baru. $^{18}$ Krisis lingkungan muncul karena kita telah membangun kode yang kurang baik untuk membaca alam, yang menyebabkan kekurangan dalam interaksi kita dengan alam. Akar penyebabnya terletak pada fondasi-fondasi pandangan dunia ilmiah kita, dan pada persepsi-persepsi yang dihasilkan pandangan dunia ini. Ia menyatakan ${ }^{19}$ :

“... most of our crises..., but arise for more fundamental reasons: they arise because we have constructed a deficient code for reading nature, leading to a deficiency in interacting with nature. The root cause lies in the very foundations of our scientific world view; and in the very perceptions which this world view engenders."

Skolimowski juga mengemukakan bahwa dalam memikirkan taktik-taktik baru untuk kehidupan, kita perlu memikirkan kembali hubunganhubungan kita dengan dunia pada umumnya, meninggalkan konsepsi dunia yang mekanistik, dan menggantikannya dengan konsepsi yang lebih luas dan lebih kaya.

\footnotetext{
${ }^{18}$ Ibid., 38

${ }^{19}$ Ibid., 2.
} 
Filsafat lingkungan berusaha memberikan dasar-dasar konsepsi alternatifnya, yakni ${ }^{20}$ :

“... in devising new tactics for living we shall need to rethink our relationships with the world at large, ... we shall need to abandon the mechanistic conception of the world, and replace it with a much broader and richer one. Ecophilosophy attempts to provide the rudiments of this alternative conception."

Filsafat lingkungan Skolimowski berusaha membawa kembali koherensi antara sistem nilai manusia dengan pandangannya atas alam semesta supaya masing-masing akan menjadi aspek yang satu bagi yang lainnya, seperti dalam kebudayaan-kebudayaan tradisional. $^{21}$ Sedangkan etika lingkungan, menurut J. Baird Callicott, sebagai subjek disiplin ilmu tersendiri, muncul pada awal 1970-an sebagai tanggapan atas situasi tahun 1960an ketika orang tiba-tiba sadar bahwa peradaban industrial telah mengakibatkan krisis lingkungan. $^{22}$ Krisis lingkungan hidup dewasa ini, menurut pendapat Arne Naess, dapat diatasi dengan melakukan perubahan cara pandang (worldview) dan perilaku manusia terhadap alam.

\footnotetext{
${ }^{20}$ Ibid., 27-28.

${ }^{21}$ Ibid., 40.

${ }^{22}$ J. Baird Callicott, "Menuju Suatu Etika
} Lingkungan Global", dalam Sunarko dan A. Eddy Kristiyanto (eds.), (2008), Menyapa Bumi Menyembah Hyang Ilahi: Tinjauan Teologis atas Lingkungan Hidup, Yogyakarta: Penerbit Kanisius, hlm. 29.
Berbagai kasus lingkungan hidup yang terjadi sekarang ini, baik pada lingkup global maupun nasional, sebagai besar bersumber dari perilaku manusia. Masalah lingkungan hidup, menurut Sonny Keraf, adalah masalah moral, persoalan perilaku manusia. Maka, perlu etika dan moralitas untuk mengatasinya. ${ }^{23}$ Dalam kajiannya dengan filsafat sendiri, apabila dilihat secara etimologi, Etika Lingkungan berasal dari dua kata, yaitu Etika dan Lingkungan. Etika berasal dari bahasa yunani yaitu "Ethos" yang berarti adat istiadat atau kebiasaan. Ada tiga teori mengenai pengertian etika, yaitu: etika Deontologi, etika Teologi, dan etika Keutamaan. $^{24}$ Maka, etika lingkungan merupakan kebijaksanaan moral manusia dalam bergaul dengan lingkungannya. Etika lingkungan diperlukan agar setiap kegiatan yang menyangkut lingkungan dipertimbangkan secara cermat sehingga

\footnotetext{
${ }^{23}$ Keraf, Sonny. (2010). Etika Lingkungan Hidup, Jakarta: Kompas, hlm.1

${ }^{24}$ Etika Deontologi adalah suatu tindakan di nilai baik atau buruk berdasarkan apakah tindakan itu sesuai atau tidak dengan kewajiban. Etika Teologi adalah baik buruknya suatu tindakan berdasarkan tujuan atau akibat suatu tindakan. Sedangkan Etika keutamaan adalah mengutamakan pengembangan karakter moral pada diri setiap orang. Lingkungan adalah segala sesuatu yang ada di sekitar manusia yang mempengaruhi kelangsungan kehidupan kesejahteraan manusia dan makhluk hidup lain baik secara langsung maupun secara tidak langsung. Jadi, etika lingkungan merupakan kebijaksanaan moral manusia dalam bergaul dengan lingkungannya.etika lingkungan diperlukan agar setiap kegiatan yang menyangkut lingkungan dipertimbangkan secara cermat sehingga keseimbangan lingkungan tetap terjaga
} 
keseimbangan lingkungan tetap terjaga. Adapun hal-hal yang harus diperhatikan sehubungan dengan penerapan etika lingkungan sebagai berikut ${ }^{25}$ :

a. Manusia merupakan bagian dari lingkungan yang tidak terpisahkan sehngga perlu menyayangi semua kehidupan dan lingkungannya selain dirinya sendiri;

b. Manusia sebagai bagian dari lingkungan, hendaknya selalu berupaya untuk menjaga terhadap pelestarian, keseimbangan dan keindahan alam;

c. Kebijaksanaan penggunaan sumber daya alam yang terbatas termasuk bahan energy;

d. Lingkungan disediakan bukan untuk manusia saja, melainkan juga untuk makhluk hidup yang lain.

Di samping itu, etika Lingkungan tidak hanya berbicara mengenai perilaku manusia terhadap alam, namun juga mengenai relasi di antara semua kehidupan alam semesta, yaitu antara manusia dengan manusia yang mempunyai dampak pada alam dan antara manusia dengan makhluk hidup lain atau dengan alam secara keseluruhan. Dalam hal ini persoalan lingkungan hidup harus dikaji dari berbagai perspektif salah satunya adalah perspektif kebijakan hukum dan perspektif moral lingkungan.

\section{Etika Lingkungan (Environmental}

Ethics) Melahirkan Asas Dasar Hukum

\section{Lingkungan Modern}

Salah satu versi teori ekosentrisme adalah teori etika lingkungan hidup yang sekarang ini populer dikenal sebagai deep ecology. Sebagai sebuah istilah, deep ecology pertama kali diperkenalkan oleh Arne Naess, seorang filsuf Norwegia, pada 1973. Naess kemudian dikenal sebagai salah seorang tokoh utama gerakan deep ecology hingga sekarang. Dalam artikelnya yang berjudul "The Shallow and the Deep, Long-range Ecological Movement: A Summary", Naess membedakan antara shallow ecological movement dan deep ecological movement. Konsep Deep ecology menuntut suatu etika baru yang tidak berpusat pada manusia, tetapi berpusat pada makhluk hidup seluruhnya dengan upaya mengatasi persoalan lingkungan hidup. Etika baru ini tidak mengubah sama sekali hubungan antara manusia dengan manusia. Bahwa, manusia dan kepentingannya bukan lagi pusat dari dunia moral. Deep ecology justru memusatkan perhatian kepada semua spesies, termasuk spesies bukan manusia. Singkatnya, kepada biosphere seluruhnya. Demikian pula, deep ecology tidak hanya memusatkan perhatian pada kepentingan jangka pendek, tetapi jangka panjang. Maka, prinsip moral yang dikembangkan

\footnotetext{
${ }^{25}$ Latifah Amir, Loc.Cit.
} 
deep ecology menyangkut kepentingan seluruh komunitas ekologis. $^{26}$

Dalam pemaknaan deep ecology, sifat holistik tidak berhenti pada pengertian hubungan fungsional antar bagian-bagian, yang pada masing-masing bagian terjadi saling ketergantungan. Lebih dari pada itu segera perlu ditambahkan adanya faktor keterhubungan dengan basis lingkungan alamiah dan basis sosialnya. Ketika berpikir tentang sepeda misalnya, persepsi yang muncul tidak hanya sebatas pada sepeda sebagai suatu keseluruhan fungsional dan karena itu mengerti kesaling-tergantungan bagian-bagiannya. Pandangan deep ecology mengenai sepeda mencakup pandangan holistik, tetapi segera ditambahkan persepsi tentang bagaimana sepeda tersebut terlekat dalam lingkungan alamiah dan sosialnya dari mana didapat bahan mentahnya, bagaimana sepeda tersebut diproduksi secara massal, bagaimana pemakaiannya mempengaruhi lingkungan alamiah dan komunitas yang memakai, dan sebagainya.

Deep ecology menurut Suwito NS mencoba memadukan aspek spiritualitas agama dengan lingkungan (ecospirituality), manusia bagian dari alam dan alam adalah suci dan sakral. Suwito berpendapat bahwa deep ecology dengan beberapa variasi temuan lebih dekat

\footnotetext{
${ }^{26}$ Keraf, Sonny. op. cit., 50.
}

dengan eko-sufisme. ${ }^{27}$ Suwito berpendapat bahwa deep ecology dengan beberapa variasi temuan lebih dekat dengan ekosufisme. $^{28}$ Eko-sufisme menurut Suwito dapat berarti sufisme berbasis ekologi, artinya kesadaran spiritual yang diperoleh dengan cara memaknai interaksi antar sistem wujud terutama pada lingkungan sekitar. ${ }^{29}$ Eko-sufisme atau green sufisme adalah konsep baru sufi yang dikonstruk melalui penyatuan kesadaran antara kesadaran berlingkungan dan juga berketuhanan. ${ }^{30}$

27 Suwito, (2011), Eko-Sufisme: Konsep, Strategi, dan Dampak, Purwokerto: STAIN Press \& Yogyakarta: Buku Litera, hlm.viii

${ }^{28}$ Orientasi pada keselamatan diri dapat diarahkan secara lebih positif dan berdampak baik pada lingkungan, jika diri/ego tersebut mencoba mengharmonikan diri pada ilahi, sesama, dan alam semesta. Lihat, Ibid.

${ }^{29}$ Ibid., hlm. 47.

30 Sedangkan perkembangan membawa para penganut etika deep ecology untuk menambahkan setidaknya delapan asas, yaitu: (1) Kesejahteraan dan keadaan baik dari kehidupan manusiawi ataupun bukan di bumi mempunyai nilai intrinsic; (2) Kekayaan dan keanekaragaman bentuk-bentuk hidup menyumbangkan kepada terwujudnya nilai-nilai ini dan merupakan nilainilai sendiri; (3) Manusia tidak berhak mengurangi kekayaan dan keanekaragaman ini, kecuali untuk memenuhi kebutuhan vitalnya; (4) Keadaan baik dari kehidupan dan kebudayaan manusia dapat dicocok-kan dengan dikuranginya secara substansial jumlah penduduk; (5) Campur tangan manusia dengan ekosistem kini terlalu besar; (6) Kebijakan umum harus dirubah, yang menyangkut struktur-struktur dasar di bidang ekonomis, teknologis, dan ideologis; (7) Perubahan ideologis terutama menghargai kualitas kehidupan dan bukan berpegang pada standar hidup yang semakin tinggi; (8) Mereka yang menyetujui butir-butir sebelumnya berkewajiban secara langsung dan tidak langsung untuk berusaha mengadakan perubahan-perubahan yang perlu. 
Adapun berdasarkan beberapa perkembangan aliran pemikiran etika lingkungan sampai pada ekosentrisme dalam konteks deep ecology. Menurut hemat penulis dapat ditarik beberapa asas dasar yang kemudian harus dianut dalam merumuskan norma lingkungan hidup yakni:

a. Asas Penghormatan Alam (Respect for Nature). Pada dasarnya semua teori hukum lingkungan mengakui bahwa alam semesta perlu untuk dihormati. Secara khusus sebagai spesies yang dominan, manusia mempunyai kewajiban moral untuk menghormati kehidupan lain dalam komunitas ekologis seluruhnya. Asas ini merupakan akar dari kearifan lokal hukum-hukum adat dan kaitannya dengan lingkungan hidup

b. Asas Tanggung Jawab Lingkungan (Moral Responsibility for Nature). Manusia sebagai bagian dari alam semesta bertanggungjawab pula untuk menjaganya. Tanggung jawab ini bukan saja bersifat individual tetapi juga kolektif. Kelestarian dan kerusakan alam merupakan tanggungjawab bersama manusia. Maka penulis mengkonsepsikan bahwa manusia yang mendominasi alam bumi adalah yang bertanggung jawab atas apa yang terjadi terhadap lingkungan. Adapun konsep ini sudah mulai dianut dalam hukum lingkungan yang merumuskan adanya asas-asas hukum seperti asas pencemar membayar (polluter-pays principle) dan asas tanggung jawab mutlak (strict liability).

\section{c. Asas Peduli Lingkungan (Caring} for Nature). Asas ini tidak didasarkan pada pertimbangan kepentingan pribadi, tetapi sematamata demi kepentingan alam. Dengan semakin peduli terhadap alam, maka manusia menjadi semakin matang dengan identitas yang kuat.

d. Asas Tidak Boleh Merusak (No Harm). Terdapat kewajiban, sikap solider dan kepedulian, paling tidak dengan tidak melakukan tindakan yang merugikan atau mengancam eksistensi makhluk hidup lain di alam semesta ini (no harm). Jadi kewajiban dan tanggung jawab moral dapat dinyatakan dengan merawat, melindungi, menjaga dan melestarikan alam, dan tidak melakukan tindakan seperti 
membakar hutan dan membuang limbah sembarangan.

\section{e. Asas Hidup dan Selaras dengan} Alam (Eco-life). Asas ini menekankan pada nilai, kualitas, cara hidup yang baik, bukan menekankan pada sikap rakus dan tamak. Ada batas untuk hidup secara layak sebagai manusia, yang selaras dengan alam.

\section{f. Asas Keadilan Lingkungan} (Environmental Justice). Asas ini menekankan bahwa terdapat akses yang sama bagi semua kelompok dan anggota masyarakat untuk ikut dalam menentukan kebijakan pengelolaan dan pelestarian serta pemanfaatan sumber daya alam. Dalam asas ini kita perlu memerhatikan kepentingan masyarakat adat secara lebih khusus, karena dalam segi pemanfaatan sumber daya alam dibandingkan dengan masyarakat modern akan kalah dari segi permodalan, teknologi, informasi dan sebagainya, sehingga kepentingan masyarakat sangat rentan dan terancam;

\section{g. Asas Integritas Moral (Moral}

Integrity). Asas ini terutama untuk pejabat publik, agar mempunyai sikap dan perilaku moral yang terhormat serta memegang teguh prinsip-prinsip moral yang mengamankan kepentingan publik, untuk menjamin kepentingan di bidang lingkungan.

Adapun menurut hemat penulis asas-asas yang dikembangkan etika lingkungan ini sangat penting diupayakan dan diimplementasikan dalam kehidupan manusia karena krisis, persoalan ekologi dan bencana aiam yang terjadi pada dasarnya diakibatkan oleh pemahaman yang salah. Yaitu bahwa alam adalah objek yang boleh diberlakukan dan dieksploitasi sekehendak kita.Pola pembangunan yang berlangsung saat ini perlu diubah dan diimplementasikan secara jelas. Aspek pembangunan tidak sematamata hanya pemenuhan kebutuhan aspek ekonomi namun juga perlu memberikan bobot yang setara pada aspek-aspek sosial, budaya dan lingkungan. Kerusakan yang terjadi pada masa sekarang, tidak hanya dirasakan oleh kita sekarang ini, namun juga akan dirasakan pula oleh generasi yang akan datang.

\section{Arah Politik Hukum Lingkungan Dalam Perspektif Ekosentrisme}

Persoalan lingkungan merupakan dalam pespektif kebijakan hukum, termasuk persoalan politik hukum. Rachmad K. Dwi Susilo menyatakan 
bahwa membicarakan politik juga berarti membicarakan kekuasaan (power) dan kewenangan (authority). Kemudian, membicarakan kedua-duanya akan sangat terkait erat dengan apa yang disebut sebagai kebijakan (policy). ${ }^{31}$ Oleh karena itu persoalan kebijakan di bidang lingkungan hidup merupakan kebijakan lingkungan hidup atau environmental policy. Kerusakan lingkungan hidup di Indonesia lebih disebabkan oleh kesalahan kebijakan negara daripada ulah tangan rakyat biasa.

Menurut Utretch, politik hukum menyelidiki perubahan-perubahan apa yang harus diadakan dalam hukum yang sekarang berlaku supaya sesuai dengan kenyataan sosial. Politik hukum membuat suatu Ius constituendum (hukum yang akan berlaku) dan berusahan agar Ius constituendum itu pada suatu hari berlaku sebagai Ius constitutum (hukum yang berlaku yang baru). ${ }^{32}$ Satjipto Rahardjo, mengemukakan bahwa politik hukum adalah aktivitas memilih dan cara yang hendak dipakai untuk mencapai suatu tujuan sosial dan hukum tertentu dalam masyarakat. Secara substansial politik hukum diarahkan pada hukum yang

31 Susilo, Rachmad K. Dwi. (2009). Sosiologi Lingkungan, Jakarta: PT. RajaGrafindo Persada, hlm. 132.

32 Abdul Latif dan Hasbih Ali, (2011), Politik Hukum, Jakarta: PT. Sinar Grafika, hlm. 22-23. seharusnya berlaku (Ius constituendum). Sedangkan pengertian Politik hukum menurut Muchtar Kusumatmadja, adalah kebijakan hukum dan perundang-undangan dalam rangka pembaruan hukum. Proses pembentukan hukum harus dapat menampung semua hal yang relevan dengan bidang atau masalah yang hendak diatur dalam undang-undang itu, apabila perundang-undangan itu merupakan suatu pengaturan hukum yang efektif. ${ }^{33}$ Adapun Padmo Wahjono menggambarkan politik hukum sebagai kebijakan penyelenggara negara yang bersifat mendasar dalam menentukan arah, bentuk maupun isi dari hukum yang akan dibentuk dan tentang apa yang dijadikan kriteria untuk menghukum sesuatu, dengan kata lain politik hukum berkaitan dengan hukum yang berlaku di masa mendatang (Ius constituendum). ${ }^{34}$

Adapun Chalid Muhammad berpandangan bahwa arah dari kebijakan hukum di bidang lingkungan hidup itu disebut dengan politik hukum lingkungan. ${ }^{35}$ Politik hukum lingkungan merupakan arah kebijakan hukum yang ditetapkan oleh negara atau pemerintah untuk mencapai tujuan dan sasaran dari

\footnotetext{
${ }^{33}$ Ibid hlm. 24

34 Imam Syaukani dan A. Ahsin Thoari,
} (2010), Dasar-Dasar Politik Hukum, Jakarta: PT. Raja Grafindo Persada, hlm. 26-27

35 Chalid Muhammad, "Pulihkan Indonesia!”, Harian Kompas, Senin, 6 Juni 2011. 
perlindungan dan pengelolaan lingkungan hidup. Namun, dalam kenyataannya hukum lingkungan seolah tidak mampu menjalankan fungsinya dengan baik dengan munculnya berbagai masalah lingkungan hidup, salah satu penyebab masalah-masalah lingkungan hidup menurut Muhammad Akib, belum dipahami, dilaksanakan, dan ditegakkannya prinsip dan norma hukum lingkungan secara komprehensif sesuai dengan politik hukumnya. ${ }^{36}$

Maka dalam hal ini arah politik hukum lingkungan terutama dalam penyelenggaraan pembangunan haruslah bersifat prolingkungan (eco-development) atau melindungi lingkungan hidup sesuai dengan prinsip pembangunan berkelanjutan (sustainable development) yang menjamin kelangsungan hidup dan terpeliharanya daya dukung lingkungan untuk kehidupan generasi-generasi selanjutnya. ${ }^{37}$ Adanya unsur-unsur dalam kebijakan yang pada hakekatnya prolingkungan sebagaimana Jimly Asshidiqie sampaikan bahwa UUD 1945 sebagai salah satu green constitution di dunia, meskipun

36 Akib, Muhammad. (2013). Politik Hukum Lingkungan: Dinamika dan Refleksinya dalam Produk Hukum Otonomi Daerah, Jakarta: PT. RajaGrafindo Persada, hlm. ix.

37 Asshidiqie, Jimly. (2010). Konstitusi Ekonomi, Jakarta: Kompas, hlm. 283. nuansa hijau masih sangat tipis (light green constitution). ${ }^{38}$

Jimly Asshidiqie mengemukakan lebih lanjut hal tersebut dengan menyatakan ${ }^{39}$ :

"Meskipun lingkungan hidup sudah dituangkan dalam Undang-Undang (UU Nomor 32 Tahun 2009 tentang Perlindungan dan Pengelolaan Lingkungan Hidup), tetapi begitu bergaul dengan UU Perdagangan, Perindustrian, (bahkan) dengan UU Koperasi saja, pasti UU LH akan kalah dalam praktiknya."

Unsur-unsur kebijakan yang prolingkungan walaupun telah diamanatkan dalam UUD 1945 dan dituangkan dalam peraturan perundangundangan terkait perlindungan dan pengelolaan lingkungan hidup, namun Pemerintah sering melakukan ketidakadilan lingkungan hidup (environmental injustice), misalnya, dalam penyelesaian dari masalah konflik industri pertambangan. Tuntutan keadilan yang diajukan masyarakat terhadap industry pertambangan besar, selama ini selalu menemukan jalan buntu. Permasalahan ini menjadi semakin rumit ketika pemerintah justru menjawab tuntutan tersebut dengan pernyataan kebijakan dan keluaran kebijakan yang mengedepankan sikap

${ }^{38}$ Ibid.

39 Asshidiqie, Jimly, "Sumber Daya Alam: Pertimbangan Ekonomi Lebih Diutamakan", Harian Kompas, Selasa, 18 Oktober 2011. 
arogan yang cenderung memihak kepada kepentingan usaha industri pertambangan dan bersandar pada logika investasi, dibanding menanggapi realitas pemiskinan masyarakat di sekitar tambang.

Permasalahan lingkungan hidup seperti di atas dikemukakan pula oleh Fritjof Capra dalam bukunya The Web of Life yang menyatakan bahwa seiring dengan berakhirnya abad ke-20, masalah lingkungan menjadi hal yang utama. Serangkaian masalah-masalah global yang membahayakan biosfer dan kehidupan manusia dalam bentuk-bentuk yang sangat mengejutkan yang dalam waktu dekat akan segera menjadi tak dapat dikembalikan lagi. ${ }^{40}$

Soal ketidakadilan lingkungan hidup (environmental injustice) yang banyak terjadi di Indonesia telah menjelma dari sebuah gagasan yang terkesan abstrak menuju sesuatu yang harus diperjuangkan, seperti ungkapan Sonny Keraf, keadilan memang harus direbut. ${ }^{41}$ Pada akhirnya agenda perubahan keadilan lingkungan tidak akan dapat mungkin dilaksanakan

\footnotetext{
40 Capra menyebutkan pandangannya bahwa "As the century draws to a close, environmental concern have become of paramount importance. We are faced with a whole series of global problems that are harming the biosphere and human life in alarming ways that may soon become irreversible."Capra, Fritjof. (1996). The Web of Life: A New Scientific Understanding of Living Systems, New York: Anchor Books, hlm. 3.

${ }^{41}$ Keraf, Sonny. (2010), Etika Lingkungan Hidup, Jakarta: Kompas, hlm. 2
}

tanpa kekuatan politik hukum yang signifikan dan luas, melibatkan berbagai elemen atau komponen penting dalam masyarakat, dan tentu saja didukung kaum intelektual yang punya komitmen pada pembaruan dengan memposisikan lingkungan pada arus utama.

Krisis lingkungan hidup global sekarang ini sebenarnya bersumber pada kesalahan fundamental-filosofis dalam pemahaman atau cara pandang manusia mengenai dirinya, alam, dan tempat manusia dalam keseluruhan ekosistem, yang dikenal dengan istilah pandangan dunia (worldview) yang diambil dari bahasa Jerman weltanschauung yang berarti perspektif atau pandangan terhadap dunia.

Pada gilirannya, kekeliruan cara pandang ini melahirkan perilaku yang keliru terhadap alam. Manusia keliru memandang alam dan keliru menempatkan diri pada konteks alam semesta seluruhnya, seperti diungkapkan Albert Schweitzer yang menyatakan, "Kesalahan terbesar semua etika sejauh ini adalah etika-etika tersebut hanya berbicara mengenai hubungan antara manusia dengan manusia." Inilah awal bencana lingkungan hidup dan karena itu, pembenahannya harus pula menyangkut pembenahan cara pandang dan perilaku manusia dalam berinteraksi, baik dengan alam maupun 
dengan manusia lain dalam keseluruhan ekosistem.

Karena pada hakekatnya persoalan lingkungan hidup juga merupakan persoalan moral, maka penyelesaian persoalan lingkungan hidup tidak dapat hanya didekati secara teknis parsial. Persoalan lingkungan hidup harus didekati secara lebih komprehensif-holistik, termasuk dalam aspek moralitas. ${ }^{42}$ Moralitas (dari kata sifat Latin moralis) menurut Bertens mempunyai arti yang pada dasarnya sama dengan "moral", hanya ada nada lebih abstrak. Moralitas adalah sifat moral atau keseluruhan asas dan nilai yang berkenaan dengan baik dan buruk. $^{43}$

Moralitas menurut Lawrence $\mathrm{M}$. Friedman adalah kehendak untuk mengikuti norma-norma, karena semua itu adalah kehendak Tuhan, atau etika yang baik, atau kewajiban agama alih-alih karena hal itu berguna bagi kita atau bagi yang lainnya. ${ }^{44} \mathrm{~K}$. Kebung memberikan pandangan terkait etika dan moral dalam hukum. Dalam moralitas, penilaian eksternal terasa penting, dan penilaian ini justru memaksa orang untuk mematuhi hukum. Jadi, yang penting adalah hukum

\section{${ }^{42}$ Ibid.}

Bertens. (2011). Etika. Jakarta: Gramedia Pustaka Utama, hlm. 6.

${ }^{44}$ Friedman, Lawrence M. (2009). Sistem Hukum Perspektif Ilmu Sosial, Bandung: Nusa Media, hlm. 146. yang bersifat mewajibkan dan kewajiban itu disertai dengan sanksi hukum. Sementara etika juga berhubungan dengan hukum, tetapi pelaksanaan atas hukum itu bukan karena kewajiban dari luar dan sanksi hukum. Pelaksanaannya sungguh didasarkan pada kesadaran batiniah pribadi (kebebasan pribadi), bahwa hukum dan peraturan itu baik bagi saya dan demi kebaikan saya sendiri. ${ }^{45}$

Nilai etika menurut Emil Salim mulanya dipengaruhi oleh pendalaman agama seseorang. Dalam perkembangan hidup manusia terdapat faktor-faktor lain yang turut mempengaruhi nilai-nilai moral manusia, yaitu kondisi lingkungan sosial dan lingkungan alam dalam mana manusia tumbuh berkembang. ${ }^{46}$ Etika adalah filsafat moral, atau ilmu yang membahas dan mengkaji secara kritis persoalan benar dan salah secara moral, tentang bagaimana harus bertindak dalam situasi konkret. Filsafat lingkungan merupakan filsafat baru yang diajukan oleh Henryk Skolimowski dengan mempertimbangkan hubungan antara satu individu dengan yang lain dan juga dengan lingkungan mereka,

45 Kebung, Konrad. (2008). Manusia Makhluk Sadar Lingkungan, Jakarta: Prestasi Pustakaraya, hlm. 39.

46 Salim, Emil (2000), Kembali Ke Jalan Lurus: Esai-esai 1966-1999, Jakarta: Alfabet, hlm. 190. 
sebagai persandingan dengan filsafat kontemporer hasil modernisme. ${ }^{47}$

Cara pandang dan perilaku manusia dalam berinteraksi, baik dengan alam maupun dengan manusia lain dalam keseluruhan ekosistem, sesungguhnya telah ada di dalam masyarakat tradisional atau masyarakat adat dengan pengetahuan tradisional (traditional knowledge)-nya yang dikenal pula dengan kearifan lokal (local customs). ${ }^{48}$ Masyarakat tradisional atau masyarakat adat dengan pengetahuan tradisionalnya lebih mampu melestarikan lingkungan hidup dibandingkan dengan kehidupan modern. Masyarakat tradisional memiliki pengetahuan yang luas dan mendalam dalam perlindungan dan pengelolaan lingkungan hidup atau alamnya masing-masing, yang digunakan untuk mengelola sumber daya dengan sebaik-baiknya. Namun, ternyata seiring perkembangan zaman, berbagai peraturan perundang-undangan pada umumnya tidak

${ }^{47}$ Diamond, Jared. (2011), Collapse: How Societies Choose to Fail or Succeed, New Hampshire: Marion Boyars Inc. sebagaimana dikutip oleh Marison Guciano, "Bangsa Tanpa Visi Ekologi”, Kompas, Jumat, 3 Februari 2012.

48 Ifrani, Fathul Achmadi Abby, Abdul Halim Barkatullah, Yati Nurhayati dan M. Yasir Said, "Forest Management Based on Local Culture of Dayak Kotabaru in the Perspective of Customary Law for a Sustainable Future and Prosperity of the Local Community", Resources, (2019), 8, 78, hlm.1-17 mengakomodasi kepentingan masyarakat adat tersebut. $^{49}$

Maka berpegang pada pergeseran pandangan terhadap alam, selanjutnya peneliti berpendapat bahwa pandangan Ekosentrisme merupakan jawaban dari permasalahan lingkungan di Indonesia. ${ }^{50}$ Ekosentrisme merupakan perkembangan dari teori etika lingkungan hidup biosentrisme. Ekosentrisme memusatkan etika pada seluruh komunitas ekologis, baik yang hidup maupun tidak. Secara ekologis, saling terkait satu sama lain. Oleh karena itu, kewajiban dan tanggung jawab moral tidak hanya dibatasi pada makhluk hidup. Kewajiban dan tanggung jawab moral yang sama juga berlaku terhadap semua realitas ekologis. ${ }^{51}$

Ekosentrisme dan Biosentrisme mendobrak pandangan Antroposentrisme yang membatasi keberlakuan etika hanya pada komunitas manusia. Keduanya memperluas keberlakuan etika untuk mencakup komunitas yang lebih luas. Pada biosentrisme, etika diperluas untuk mencakup komunitas biotis. Sementara

49 Eko Nurmadiansyah, (2014), “EcoPhilosophy dan Implikasinya Dalam Politik Hukum Lingkungan Di Indonesia” Jurnal Melintas, Vol.30, No.1, 2014, hlm.70-104.

50 Nurul Listiyani dan M.Yasir Said, "Political Law on the Environment: The Authority of the Government and Local Government to File Litigation in Law Number 32 Year 2009 on Environmental Protection and Management." Resources, (2018), 7, 77, hlm.8

${ }^{51}$ Ibid., hlm. 47 . 
pada ekosentrisme, etika diperluas untuk mencakup ekologis seluruhnya. ${ }^{52}$

Etika ekosentris ini berakar dalam cara berpikir yang holistik, dan bukan mekanistik, tentang seluruh kenyataan. Cara berpikir yang holistik (utuhmenyeluruh) ini mempunyai 5 (lima) asumsi, sebagai berikut ${ }^{53}$ :

1. Segala yang ada itu berhubungan satu sama lain hingga membentuk satu keseluruhan. Keseluruhan (totalitas) itu mempengaruhi setiap bagian pembentuknya; dan sebaliknya, perubahan yang terjadi di dalam salah satu bagian akan ikut merubah bagian yang lainnya serta keseluruhan itu pula. Jadi, misalnya, dalam sebuah ekosistem terjadi begitu banyak perubahan dalam bagian-bagiannya, pada akhirnya seluruh ekosistem itu akan ambruk;

2. Keseluruhan itu lebih besar daripada sekadar jumlah bagianbagian pembentuknya. Prinsip yang mengatur suatu ekosistem bukanlah prinsip identitas yang menyatakan bahwa keseluruhan itu identic dengan jumlah total bagianbagiannya, melainkan prinsip sinergi: penggabungan beberapa kekuatan menjadi satu kesatuan akan menghasilkan daya serta dampak yang lebih besar daripada bila masingmasing kekuatan itu bekerja sendiri;

3. Makna itu tergantung dari konteks. Berbeda dari mekanisme yang menandaskan bahwa setiap hal itu bersifat mandiri dan bisa dimengerti secara terisolir, maka

${ }^{52}$ Ibid., hlm.92

53 Sugiharto, I. Bambang dan Agus Rachmat, (2000), Wajah Baru Etika dan Agama, Yogyakarta: Kanisius, hlm. 75-76. holisme itu menandaskan bahwa setiap hal atau peristiwa itu memperoleh maknanya berkat hubungannya dengan hal lain dan berkat peranannya dalam keseluruhan;

4. Proses lebih utama daripada bagian-bagiannya. Suatu keseluruhan tertentu, misalnya suatu sistem sosial atau biologis, itu selalu bersifat terbuka serta dinamis, artinya senantiasa terdapat pertukaran serta perputaran materi dan energi antara suatu sistem dengan lingkungannya. Bagianbagian pembentuk suatu keseluruhan tidaklah bersifat permanen, tetapi senantiasa berubah serta berganti berkat proses pertukaran dan perputaran energi tadi. Akibatnya, selalu bisa timbul hal serta susunan keseluruhan yang baru. Proses perubahan serta kreativitas itu adalah ciri hakiki dari kenyataan;

5. Manusia dan lingkungan alam yang bukan manusia itu membentuk satu kesatuan. Dalam holisme, tidak terdapat pertentangan dualistic di antara alam/kebudayaan. Manusia dan alam dipandang sebagai dua belahan dari satu sistem organisme kosmik yang sama. Dengan kata lain, holisme itu lebih memperhatikan kesinambungan, dan bukan pertentangan, di antara manusia serta alam dan berusaha mempelajari pengaruh timbal balik di antara manusia/masyarakat dengan lingkungan alamiahnya.

Adapun melihat politik hukum lingkungan sekarang ini (ius constitutum) baik di Indonesia maupun dalam perspektif Hukum Lingkungan Internasional sudah mulai masuk kearah etika lingkungan 
berbasis ekosentrisme dengan dianutnya suatu asas preventif yang disebut sebagai Asas Pencemar Membayar (Polluter-Pays Principle). Asas pencemar membayar menandakan bahwa adanya hak lingkungan untuk mendapat ganti rugi. Hal ini berarti sebagai perwujudan keadilan korektif terhadap lingkungan hidup. Adapun lingkungan hidup menurut aliran ekosentrime apabila dikaitkan dengan teori keadilan korektif oleh Aristoteles, dapat dimaknai sebagai adanya suatu 'hak' yang diberikan kepada lingkungan hidup untuk dapat mempertahankan kelestariannya dan memperoleh perbaikan atas pencemaran dan kerusakan yang disebabkan oleh manusia atau perbuatan manusia yang mempengaruhi ekosistem alam. Sedangkan untuk menentukan arah ius constituendum hukum lingkungan Indonesia diperlukan adanya kebijakan untuk menentukan arah etika dan moral yang dikonkretkan pada fokus perbaikan budaya hukum (legal culture) daripada semata-mata berkutat pada substansi hukum (legal substance).

\section{PENUTUP}

\section{Kesimpulan}

Secara singkat dapat disimpulkan bahwa: Pertama, pemikiran etika lingkungan dalam perspektif ekosentrisme dan ekosufisme sesungguhnya telah ada di dalam masyarakat tradisional atau masyarakat adat dengan pengetahuan tradisional (traditional knowledge)-nya yang dikenal pula dengan kearifan lokal (local customs).

Kedua, dalam politik hukum lingkungan ius constitutum adanya asasasas seperti asas pencemar membayar menandakan bahwa adanya hak lingkungan untuk mendapat ganti rugi. Adapun lingkungan hidup menurut aliran ekosentrime apabila dikaitkan dengan teori keadilan korektif oleh Aristoteles, dapat dimaknai sebagai adanya suatu 'hak' yang diberikan kepada lingkungan hidup untuk dapat mempertahankan kelestariannya dan memperoleh perbaikan. Sedangkan untuk menentukan arah ius constituendum hukum lingkungan Indonesia diperlukan fokus perbaikan budaya hukum daripada sematamata berkutat pada substansi hukum.

\section{Saran}

Pembangunan yang dilakukan harus merupakan pembangunan berbasis lingkungan (eco-development) yang selalu selaras dengan keseimbangan alam. Pembangunan yang berkelanjutan dan berwawasan lingkungan. Dari beberapa pembahasan di atas, bahwa kita di tuntut untuk menjaga lingkungan. Dalam menjaga lingkungan, manusia harus memiliki "etika". Etika lingkungan ini adalah sikap kita dalam menjaga 
kelestarian alam ini agar alam ini tidak rusak, baik ekosistem maupun habitatnya. Perlu kita sadari bahwa kita ini juga nagian dari alam ini. Maka kita harus menjaga lingkungan ini dengan baik dengan normanorma etika lingkungan.

\section{DAFTAR PUSTAKA}

\section{Buku}

Akib, Muhammad. (2013). Politik Hukum Lingkungan: Dinamika dan Refleksinya dalam Produk Hukum Otonomi Daerah, Jakarta: PT. RajaGrafindo Persada, hlm. ix.

Abdul Latif dan Hasbih Ali, (2011), Politik Hukum, Jakarta: PT. Sinar Grafika, hlm. 22-23.

Asshidiqie, Jimly. (2010). Konstitusi Ekonomi, Jakarta: Kompas, hlm. 283.

Bertens. (2011). Etika. Jakarta: Gramedia Pustaka Utama, hlm. 6.

Bambang Sugiharto, "Filsafat dan Pengalaman", Pengantar buku Gaarder, Jostein. (1996), Dunia Sophie: Sebuah Novel Filsafat, Bandung: Mizan, hlm. 14-15.

Capra, Fritjof. (1996). The Web of Life: A New Scientific Understanding of Living Systems, New York: Anchor Books, hlm. 3.

Daniel Callahan dalam Ginting. (2012). Teori Etika Lingkungan, Bali: Udayana University Press, hlm. 13.
Diamond, Jared. (2011), Collapse: How Societies Choose to Fail or Succeed, New Hampshire: Marion Boyars Inc.

Danusaputro, Munadjat. (1986). Hukum Lingkungan dalam Pencemaran Lingkungan Melandasi Sistem Hukum Pencemaran, Bandung: Bina Cipta, hlm. 77.

Friedman, Lawrence M. (2009). Sistem Hukum Perspektif Ilmu Sosial, Bandung: Nusa Media, hlm. 146.

Fajar, Mukti dan Yulianto Ahmad, (2009), Dualisme Penelitian Hukum: Normatif dan Empirirs, Yogyakarta: Pustaka Pelajar, hlm. 33- 38

Imam Syaukani dan A. Ahsin Thoari, (2010), Dasar-Dasar Politik Hukum, Jakarta: PT. Raja Grafindo Persada, hlm. 26-27

J. Baird Callicott, "Menuju Suatu Etika Lingkungan Global", dalam Sunarko dan A. Eddy Kristiyanto (eds.), (2008), Menyapa Bumi Menyembah Hyang Ilahi: Tinjauan Teologis atas Lingkungan Hidup, Yogyakarta: Penerbit Kanisius, hlm. 29.

Keraf, Sonny. (2010), Etika Lingkungan Hidup, Jakarta: Kompas, hlm. 2

Kebung, Konrad. (2008). Manusia Makhluk Sadar Lingkungan, Jakarta: Prestasi Pustakaraya, hlm. 39.

Kattsoff, Louis O. (2004), Pengantar Filsafat, Yogyakarta: Penerbit 
Tiara Wacana Yogya, hlm. 455.

Marzuki, Peter Mahmud. (2005). Penelitian Hukum, Jakarta: Kencana., hlm. 35

Roderick Nash, Frazier. (1989). The Rights of Nature: A History of Environmental Ethics, terbitan University of Wisconsin Press.

Suwito, (2011), Eko-Sufisme: Konsep, Strategi, dan Dampak, Purwokerto: STAIN Press \& Yogyakarta: Buku Litera, hlm.viii

Stewart, Richard and James E Krier. (1978). Environmental Law and Policy, New York: The Bobbs Merril Co. Indianapolis, hlm. 3-5.

Supariadi. (2008). Hukum Lingkungan Indonesia Sebuah Pengantar, Jakarta: Sinar Grafika, hlm. 40.

Soerjono Soekanto dan Sri Mamuji, (1995), Penelitian Hukum Normatif , Suatu Tinjauan Singkat, Jakarta: RajaGrafindo, hlm. 15.

Skolimowski, Henryk. (1981). Ecophilosophy: Designing New Tactics for Living. New Hampshire: Marion Boyars Inc.,hlm. 21.

Sugiharto, Bambang. (1996). Postmodernisme: Tantangan Bagi Filsafat. Yogyakarta: Kanisius, hlm. 29.

Susilo, Rachmad K. Dwi. (2009). Sosiologi Lingkungan, Jakarta: PT.
RajaGrafindo Persada, hlm. 132.

Salim, Emil (2000), Kembali Ke Jalan Lurus: Esai-esai 1966-1999, Jakarta: Alfabet, hlm.190.

Sugiharto, I. Bambang dan Agus Rachmat, (2000), Wajah Baru Etika dan Agama, Yogyakarta: Kanisius, hlm. 75-76.

\section{Jurnal dan Publikasi Ilmiah Lain}

Eko Nurmadiansyah, (2014), “EcoPhilosophy dan Implikasinya Dalam Politik Hukum Lingkungan Di Indonesia" Jurnal Melintas, Vol.30, No.1, 2014, hlm.70-104.

Ifrani, Fathul Achmadi Abby, Abdul Halim Barkatullah, Yati Nurhayati dan M. Yasir Said, "Forest Management Based on Local Culture of Dayak Kotabaru in the Perspective of Customary Law for a Sustainable Future and Prosperity of the Local Community", Resources, (2019), 8, 78, hlm.1-17

Nurul Listiyani dan M.Yasir Said, "Political Law on the Environment: The Authority of the Government and Local Government to File Litigation in Law Number 32 Year 2009 on Environmental Protection and Management." Resources, (2018), 7, 77, hlm.8

$\begin{array}{ccr}\text { Yati Nurhayati, } & \text { "Perdebatan } & \text { Antara } \\ \text { Metode } & \text { Normatif } & \text { Dengan } \\ \text { Metode } & \text { Empirik } & \text { Dalam } \\ \text { Penelitian } & \text { Ilmu } & \text { Hukum }\end{array}$


Ditinjau Dari Karakter, Fungsi, dan Tujuan Ilmu Hukum" Jurnal Al Adl, Vol 5, No 10 (2013), hlm.15

\section{Media Massa dan Website}

Asshidiqie, Jimly, "Sumber Daya Alam: Pertimbangan Ekonomi Lebih Diutamakan", Harian Kompas, Selasa, 18 Oktober 2011.

Chalid Muhammad, "Pulihkan Indonesia!" Harian Kompas, Senin, 6 Juni 2011.

Erri Megantara, "Pendekatan Pembangunan Antroposentris v Ekosentris", Koran Republika, 11 Januari 1997,

Marison Guciano, "Bangsa Tanpa Visi

Ekologi”, Kompas, Jumat, 3

Februari 2012. 